DOI: 10.17951/lrp.2019.38.3.207-220

\author{
ANGELIKA BARCZYK-Nessel \\ Państwowa Uczelnia im. Stefana Batorego w Skierniewicach \\ Wydział Ekonomii i Administracji, Instytut Nauk Społecznych \\ ORCID - 0000-0002-2839-203X
}

\title{
DETERMINANTY KIEROWANEGO \\ DOSKONALENIA ZAWODOWEGO NAUCZYCIELI W WARUNKACH PLACÓWKI WYCHOWANIA PRZEDSZKOLNEGO
}

\begin{abstract}
Streszczenie: Autorka artykułu podjęła problematykę uwarunkowań doskonalenia zawodowego nauczycieli przedszkola, ze szczególnym uwzględnieniem roli dyrektora. Celem doskonalenia zawodowego sterowanego przez dyrektora przedszkola jest przede wszystkim usprawnianie pracy nauczyciela, a pośrednio doskonalenie pracy przedszkola. Dlatego ważne jest, aby dyrektor stwarzał odpowiednie warunki do realizacji tych celów, są to bowiem cele wspólne i tylko wspólnie mogą być realizowane. Umiejętne kierowanie doskonaleniem nauczycieli przez dyrektora placówki oświatowej to warunek niezbędny nowoczesnego sprawowania nadzoru pedagogicznego.
\end{abstract}

Słowa kluczowe: nauczyciel przedszkola, doskonalenie zawodowe, hospitacja, samokształcenie

System kształcenia, dokształcania i doskonalenia nauczycieli jest częścią systemu oświaty i całej edukacji. Nauczyciel pełni wiodącą rolę w uczeniu realnego życia, wielostronności kształcenia i wychowania - powinien więc charakteryzować się wysoką kulturą pedagogiczną i etyką zawodu nauczycielskiego oraz samoświadomością zawodową (Duraj-Nowakowa 2002, s. 213). Wywiera on duży wpływ na rozwój wychowanków, a efekty jego pracy wpływają zarówno na indywidualne losy dzieci, jak i na rozwój całego społeczeństwa. Błędy nauczyciela przynoszą szkody społeczne, w szczególności zaś krzywdzą dzieci. Nic dziwnego więc, że „prawidłowy stosunek do błędów i niepowodzeń wychowawczych został uznany za podstawowe kryterium mistrzostwa pedagogicznego" (Filipowicz, Rataj 1988, s. 277). 
Z powodu ważkich społecznie zadań stawia się nauczycielom wysokie wymagania zwłaszcza w dziedzinie kultury zawodowej, której elementami są: odpowiednia postawa społeczno-moralna, wysoka wiedza pedagogiczna i z dziedzin pokrewnych, a także twórczy stosunek do stawianych przed nimi zadań. Osiągnięcie wysokiego poziomu kultury zawodowej zmusza niejako nauczycieli do ustawicznego samokształcenia. Dlatego też wiele uwagi przywiązuje się do podnoszenia kwalifikacji zawodowych oraz możliwości udziału w różnych formach doskonalenia pracy nauczycieli. Właściwością zawodu nauczycielskiego jest bowiem konieczność kształcenia się przez cały czas wykonywania pracy dydaktyczno-wychowawczej (Parzęcki 2002, s. 32-36).

Według Wincentego Okonia doskonalenie nauczycieli to ważny składnik systemu kształcenia pozaszkolnego nauczycieli polegający na:

- udzielaniu pomocy początkującym nauczycielom w okresie adaptacji do zawodu;

- aktualizowaniu wiedzy przedmiotowej i pedagogicznej, zaznajamianiu z postępami nauki, udzielaniu pomocy w rozszerzaniu lub zmianie specjalizacji (w okresie samodzielności zawodowej);

- organizowaniu różnych form samokształcenia indywidualnego i zbiorowego;

- udzielaniu pomocy w samodzielnej pracy badawczej (Okoń 1992, s. 57-58).

Ustawiczne doskonalenie pracy nauczyciela jest warunkiem koniecznym do osiągnięcia pełnego rozwoju zawodowego. Obejmuje ono wiele form i metod mających na celu podnoszenie kwalifikacji, wiedzy kierunkowej, umiejętności pedagogicznych i samokształcenia. Doskonalenie powinno łączyć formy obligatoryjne i fakultatywne, mieć charakter doraźny i okresowy, wewnątrzszkolny i zewnętrzny (Magda-Adamowicz 2008, s. 93-95). Ważne jest, aby było ono prowadzone przez wyspecjalizowane instytucje, takie jak ośrodki metodyczne czy wyższe uczelnie. Należy pamiętać również o zasadach integracji teorii z praktyką, różnorodności i dostępności form dla nauczycieli. Skutkiem doskonalenia nauczycieli powinno być podnoszenie efektywności ich pracy, a także rozwój osobowości, samorealizacji i motywacji do zawodu (Pery, Dobrzyńska 2000, s. 2-7).

Znaczącą rolę w doskonaleniu zawodowym nauczycieli powinni pełnić dyrektorzy przedszkoli, gdyż są oni pierwszymi doradcami metodycznymi i organizatorami różnych form doskonalenia na terenie swoich placówek (Banach 1997, s. 294-295). Bezpośredni nadzór sprawowany przez dyrektora jest najbliższy nauczycielowi, ponieważ uwzględnia kontrole wyników na tle jego indywidualnych możliwości i warunków społecznych. Dotyczy różnorodnych zadań wykonywanych przez nauczyciela na różnych etapach pracy (Pilch 2002, s. 8).

Sprawne prowadzenie nadzoru pedagogicznego wymaga od dyrektora nieustannego uzupełniania wiedzy pedagogicznej i samodoskonalenia się. Współ- 
czesny dyrektor przedszkola powinien być innowatorem posiadającym zarówno dużą wiedzę ogólną, jak i pedagogiczną oraz z zakresu organizacji i zarządzania. Wiedza ta pozwoli mu bowiem na dążenie do optymalnego rozwoju nauczycieli, a w konsekwencji - pełnego rozwoju wychowanków (Barański 1997/1998, s. 4-5).

Doskonalenie własnych kwalifikacji przez dyrektora przedszkola wiąże się ściśle z wdrażaniem nauczycieli do samowychowania i samokształcenia. Stworzenie odpowiednich warunków, umiejętność indywidualnego podejścia do każdego z nauczycieli, jest $z$ kolei podstawą harmonijnego i spójnego rozwoju zawodowego. Dyrektor oprócz wspierania, rozumienia i akceptowania nauczyciela jest odpowiedzialny za aranżowanie jego uczenia się, co stanowi istotę pracy nauczycielskiej (Miszczyk 2001, s. 2).

Dobry dyrektor powinien współpracować z nauczycielem na zasadzie dobrze rozumianej komunikacji, rozwijania u niego zachowań asertywnych, budowania wzajemnego zaufania oraz rozwijania empatii i zrozumienia. Taka postawa dyrektora stwarza możliwość wspólnego działania, wyzwala inwencję twórczą u nauczycieli, a także pomaga w wypracowaniu własnego stylu pracy.

Warunkiem powadzenia działalności dydaktyczno-wychowawczej jest stworzenie odpowiedniej atmosfery wśród grona pedagogicznego. Atmosfera w zespole jest wynikiem stosunków społecznych, następstwem uznania dla ludzi i poszanowania ich godności.

Kultura zawodowa dyrektora ma istotne znaczenie dla zharmonizowania wszystkich elementów układu społecznego i jej powiązania ze środowiskiem w zwartym systemie wychowawczo-dydaktycznym.

Ani autokratyzm, ani liberalizm nie sprzyjają zdobywaniu przez dyrektora niezbędnego autorytetu. Pomaga natomiast w jego uzyskaniu życzliwość i chęć pomocy nauczycielom. Autorytet dyrektora wynika nie z pełnionej funkcji czy zajmowanego stanowiska, lecz posiadanej wiedzy, kultury osobistej, taktu, umiejętności współżycia społecznego i moralności. Taki autorytet nie krępuje nauczycieli, przeciwnie - podnosi wiarę w ich własne możliwości, wyzwala inicjatywę, zachęca do współpracy, wymiany doświadczeń oraz stałego poszerzania wiedzy i kwalifikacji zawodowych. Aprobata poczynań nauczycieli sprzyja dobrej pracy i stwarza warunki do umocnienienia pozytywnej motywacji do samodoskonalenia (Plewka 2009, s. 27 i nn.).

Bardzo ważnym elementem tworzenia właściwej atmosfery w placówce jest zapewnienie dobrej komunikacji dotyczącej spraw służbowych, aktualnych aktów prawa oświatowego, a także wyników pracy nauczycieli zatrudnionych w przedszkolu. Do udzielania tych informacji zobowiązany jest dyrektor przedszkola, który $\mathrm{w}$ toku dyskusji podczas rad pedagogicznych uzyskuje orientację o rzeczywistych możliwościach wszystkich pracowników, ich umiejętnościach, zainteresowaniach itp. (Puchalski 2004, s. 33-36). 
Jak słusznie zauważył Okoń, doskonalenie zawodowe to „podwyższanie kwalifikacji pracowniczych za pośrednictwem różnych form kształcenia i samouctwa" (Okoń 1992, s. 58). Wyróżnia się trzy podstawowe funkcje doskonalenia zawodowego:

- funkcję wyrównawczą - polegającą na uzupełnianiu wykształcenia do poziomu wymaganego przez wykonywany zawód, w przypadku podjęcia pracy przez osobę nieposiadającą pełnych kwalifikacji;

- funkcję wdrożeniową - sprowadzającą się do nabywania wiadomości i sprawności praktycznych już w trakcie wykonywania pracy;

- funkcję renowacyjną - wiążącą się ze stałym unowocześnianiem zasobów wiedzy i sprawności pracownika, w związku z postępem w danej dziedzinie pracy (Okoń 1992, s. 58).

Nowoczesne przedszkole powinno być przedszkolem samodoskonalącym się, co oznacza, że przez długi okres należy dochodzić do coraz lepszej pracy całego zespołu osób. Wymaga to jednak od współpracujących ze sobą jednostek takich działań, jak:

- zbiorowej refleksji polegającej na rozwiązywaniu różnorodnych problemów;

- wspólnego uczenia się nowych zachowań;

- myślenia cyklicznego, wymagającego oceny wyników zrealizowanego zadania oraz wyciągnięcia wniosków dotyczących usprawniania kolejnych działań (Bury, Matczak 2007, s. 2-3).

$\mathrm{W}$ „samodoskonalącym się" przedszkolu wszyscy jego pracownicy są jednakowo ważni i wszyscy mają prawo decydować o pożądanych zmianach. Dyrektor przedszkola powinien ze wszystkimi pracownikami organizować narady poświęcone temu, co można zmienić na lepsze. Dobrze byłoby, gdyby narady odbywały się w miarę regularnie i zostały wpisane na stałe w kalendarz narad (Elsner 2000, s. 71).

Danuta Elsner proponuje tu dwie odmiany dyskusji efektywnych. Pierwszą z nich jest dyskusja okrągłego stołu (przy mniejszej liczbie osób), kiedy to uczestnicy otrzymują wcześniej problem do rozwiązania praktycznego i kolejno zgłaszają swoje propozycje wraz z uzasadnieniem. Drugą zaś - dyskusja wielokrotna (wymagana większa liczba osób), kiedy to dyskutanci formułują pytanie, na które będzie poszukiwana odpowiedź. Uczestnicy takiej narady dzielą się na zespoły, w których wybierają przewodniczących. Następnie każdy zespół pracuje w innym pomieszczeniu, poszukując odpowiedzi na postawione pytania. Wynikiem narady jest ustalenie listy rozwiązań przyjętych do realizacji. Na tym właśnie polega istota „cyklicznego myślenia”. Doskonalenie przedszkola powinno być stałą analizą tego, co można zmienić na lepsze, ustalaniem planu korzystnych zmian oraz oceną jego realizacji i korektą wcześniejszych ustaleń (Elsner 1997, s. 191 i nn.).

Jak już wcześniej wspomniano, dużą rolę w motywowaniu do doskonalenia zawodowego odgrywa dyrektor przedszkola, który powinien stworzyć odpowiednie 
warunki organizacyjne umożliwiające nauczycielom korzystanie $\mathrm{z}$ różnych form doskonalenia zawodowego, m.in. hospitacji, zespołów samokształceniowych, szkoleniowych rad pedagogicznych, a także warsztatów i spotkań metodycznych (Elsner 2004, s. 35-37).

Dyrektor przedszkola $\mathrm{z}$ jednej strony powinien zapewnić warunki do realizacji zadań dydaktyczno-wychowawczych nauczycielom, a z drugiej ocenić całokształt działalności placówki. Maria Łaciak (1986, s. 97) utożsamia kontrolę pracy nauczyciela z hospitacją zajęć dydaktyczno-wychowawczych:

- zorganizowanych przez nauczyciela,

- indywidualnych z dziećmi,

- popołudniowych,

- współdziałania ze środowiskiem.

Hospitacje prowadzone przez dyrektora spełniają swoje zadanie pod warunkiem, że będą prowadzone na zasadzie dobrze przyjętego partnerstwa, wszechstronności, dokładnej analizy procesu nauczania, będą różnorodne, systematyczne, szczegółowe i dokładnie omówione.

Kazimierz Marcinkiewicz hospitację porównuje do lustra, w którym nauczyciel prowadzący zajęcia $\mathrm{z}$ dziećmi przegląda się, aby dokonać poprawek. Hospitacja jest dyskusją, wspólną analizą procesu dydaktyczno-wychowawczego w celu wyboru najlepszej drogi postępowania nauczyciela wychowania przedszkolnego prowadzącej do rozwoju podopiecznych. Dotyczy to zarówno hospitacji prowadzonych w ramach nadzoru pedagogicznego, jak i lekcji pokazowych, będących odmianą hospitacji (Marcinkiewicz 1996, s. 7). Joanna Chmiel stwierdza, że „dyrektor hospitując zajęcia, ocenia wyniki, efekty pracy z dziećmi, a nie zastosowane metody i organizację zajęć. Cel kształcenia jest określony jako zamierzony wynik ucznia, dziecka, a metody i zastosowane zasady nauczania temu celowi są podporządkowane (Elsner 1997, s. 216-217). Polega to na uzmysłowieniu sobie, jakie cele muszą osiągnąć dzieci po opanowaniu danej części programu nauczania.

Marcinkiewicz wymienia dwa rodzaje hospitacji:

- globalne - pozwalające na ogólne spojrzenia na wszystkie lub większość elementów procesu kształcenia i wychowania, dzięki czemu można zaobserwować ogólne przygotowanie i zaangażowanie nauczyciela, stosowanie ogólnych założeń dydaktyczno-wychowawczych itp.;

- wycinkowe - umożliwiające analizę jednego lub kilku elementów procesu dydaktyczno-wychowawczego (Marcinkiewicz 1996, s. 7).

Inne możliwości pracy hospitacyjnej dyrektora przedszkola przedstawił Stefan Wlazło (Elsner 1997, s. 212-216), który stwierdził, że hospitacja stwarza szanse rozwoju, gdyż jest ustaleniem pewnego stanu pozwalającego zaprojektować modyfikacje, a nawet zmiany. Podzielił on hospitacje na: 
- kontrolno-oceniające, których celem jest stwierdzenie, jaki poziom pracy prezentuje nauczyciel w aktualnym stadium rozwoju zawodowego;

- doradczo-doskonalące, w których dyrektor diagnozuje mocne i słabe strony warsztatu pracy nauczyciela;

- diagnozujące, które polegają na stwierdzeniu, jaki poziom umiejętności i wiedzy opanowały dzieci w stosunku do wymagań programowych.

Z kolei jeszcze inny podział hospitacji podała Krystyna Duraj-Nowakowa:

- hospitacja całościowa, obejmująca całokształt pracy nauczyciela, pozwalająca ocenić stopień realizacji programu i ogólnych założeń dydaktyczno-wychowawczych systemu oświatowego;

- hospitacja problemowa, realizowana wówczas gdy hospitujący wspólnie $\mathrm{z}$ hospitowanym lub sam uzgadnia zagadnienia i poszukuje rozwiązania wcześniej sformułowanego problemu (Duraj-Nowakowa 1981, s. 103-105).

Autorka ta zaproponowała również inną nomenklaturę i kryterium podziału hospitacji na: kompleksowe, problemowe oraz lustracje (inspekcje), mające charakter okazjonalny, dorywczy i niekoniecznie powiązany z oglądanymi zajęciami. Natomiast ze względu na sposób planowania autorka podzieliła hospitacje na planowe, nieplanowe oraz bez uprzedzenia prowadzącego o zamiarze hospitowania go (Duraj-Nowakowa 1981, s. 103-105).

W przedszkolu, tak jak i w innych placówkach oświatowych, mogą być stosowane zarówno hospitacje zapowiedziane, jak i niezapowiedziane. Zdaniem Łaciak „hospitacje niezapowiedziane mobilizują nauczycieli do systematycznej realizacji programu, powodują jednak u niektórych $\mathrm{z}$ nich podejrzenie, nieufność, a nawet stresy. Natomiast hospitacje zapowiedziane wyzwalają inicjatywę zmierzającą do doskonalenia, poszukiwania nowych metod i form pracy, szukania rozwiązania trudności, mobilizują do postępu pedagogicznego" (Łaciak 1986, s. 97).

Z kolei zdaniem Edwarda Gawlikowskiego hospitowanie zajęć powinno prowadzić do „racjonalnego wykorzystania spostrzeżeń zdobytych w toku obserwacji procesu nauczania oraz [...] utrzymywać ład pedagogiczny zapewniający sprawność szkoły" (Gawlikowski 1971, s. 7). Z tego względu hospitację uważa się od dawna za jedną $\mathrm{z}$ głównych form nadzoru pedagogicznego.

Zasadniczym celem hospitacji jest stwierdzenie czy proces nauczania i wychowania odbywa się prawidłowo, czy nauczyciel osiąga zamierzone wyniki prace określone przez program dydaktyczno-wychowawczy. Według Marcinkiewicza celem hospitacji jest:

- diagnoza pracy nauczyciela lub dyrektora szkoły;

- prognoza dalszego rozwoju, samokształcenia czy niezbędnego doskonalenia i dokształcania;

- korelowanie tematyki, dostosowanie sposobów i metod kształcenia, przyjmowania celów prowadzonych zajęć; 
- kształcenie krytycznego spojrzenia i pomocy w eliminowaniu popełnionych błędów oraz wyborze najlepszych rozwiązań;

- ocena obecnego stanu (Marcinkiewicz 1996, s. 7).

Hospitowanie zajęć nie jest rzeczą łatwą. Pogląd ten przedstawił Gawlikowski, stwierdzając, że „hospitowanie lekcji wraz z analizą lekcji (lub szeregu lekcji), oceną i udzielaniem hospitowanemu konstruktywnego komentarza w celu zmodyfikowania postępowania jest czynnością trudną, skomplikowaną i bardziej odpowiedzialną niż inne czynności [...] dyrektora" (Gawlikowski 1971, s. 7). Zbyt powierzchowna obserwacja może doprowadzić do wyciągnięcia nieprawdziwych wniosków o pracy danego nauczyciela. Hospitujący powinien zaś poznać faktyczny stan wiedzy, przyrost wiadomości, umiejętności i nawyków dzieci.

Halina Dziuk opracowała ogólny schemat procesu prowadzenia hospitacji składający się z takich etapów, jak:

- planowanie,

- przygotowanie do hospitacji,

- hospitacja,

- przygotowanie do rozmowy,

- rozmowa pohospitacyjna (Dziuk 1994, s. 2-3).

Planowanie hospitacji jest bardzo ważnym jej elementem (Dziuk 1994, s. 2-3; Kowolik, Pośpiech 2009, s. 139). Dyrektor przy pomocy pozostałej kadry kierowniczej powinien opracować problematykę hospitacji na każdy rok szkolny (najpóźniej w sierpniu). Wynika ona z analizy i oceny efektów pracy dydaktyczno-wychowawczej i opiekuńczej w roku ubiegłym. Układając plan, powinien dokonać analizy sprawowanego nadzoru, najważniejszych potrzeb, zadań i okoliczności, korzystając z wniosków i zaleceń oraz wytycznych organu sprawującego nadzór pedagogiczny. Harmonogram hospitacji powinien uwzględniać wszystkie zajęcia, każdy zespół dzieci, każdego nauczyciela - niezależnie od rodzaju zawartego z nim stosunku pracy.

Kolejnym etapem hospitacji jest przygotowanie do niej. Etap ten obejmuje zapoznanie się z programem, rozkładem, metodyką prowadzonych zajęć oraz wynikami pracy - przez osobę hospitującą. Wstępnym elementem jest przeprowadzenie rozmowy przedhospitacyjnej w celu zapoznania się z tematem, celami, organizacją zajęć, stosowanymi metodami, formami, środkami dydaktycznymi oraz przemyślenie planu hospitacji. Ważne jest także zapoznanie się z trudnościami $\mathrm{w}$ pracy nauczyciela oraz rozliczenie go z czynności pohospitacyjnych.

Po przeprowadzeniu tych czynności następuje hospitacja właściwa, czyli bezpośrednie obserwowanie zajęć bez ingerencji w ich zaplanowany temat i tok. Istotne jest również przygotowanie się dyrektora do rozmowy pohospitacyjnej.

W przygotowaniu rozmowy pohospitacyjnej uwzględnia się spostrzeżenia i uwagi, wychodząc od pozytywnych do negatywnych oraz zalecenia bądź rady. 
Rozmowa pohospitacyjna powinna być przeprowadzona $\mathrm{w}$ tym samym dniu lub najpóźniej trzy dni po hospitacji. Przeprowadzenie rozmowy uważa się za najtrudniejszy z elementów hospitacji. Wymaga bowiem od hospitującego taktu, ale i dobrego przygotowania metodycznego. Omawianie zajęć powinno zaczynać się od samooceny nauczyciela wraz z ustosunkowaniem do przebiegu i wyników, osiągniętych celów, niedociągnięć czy ewentualnych trudności w jej realizacji. Następnie hospitujący dokonuje oceny zajęć, udzielając nauczycielowi instruktażu do dalszej pracy. Stosowaną formą uwag pohospitacyjnych są rady i wskazówki. Należy ponadto pamiętać, że wydanie zaleceń wymaga ich kontroli.

Aby rozmowa pohospitacyjna nie była chaotyczna, a instruktaż był konstruktywny, warto ją uporządkować według następujących zagadnień:

- temat zajęć - powinien być konkretny, właściwie wyodrębniony z programu;

- osiągnięcie celów wychowawczo-dydaktycznych;

- zastosowanie odpowiednich zasad nauczania i wychowania, w tym m.in. świadomego i aktywnego udziału wychowanka, systematyczności i logicznej kolejności, trwałości wyników nauczania (ile dzieci zapamiętały i zrozumiały);

- zastosowanie odpowiednich metod;

- zastosowanie odpowiednich form pracy;

- zastosowanie środków dydaktycznych - dostosowanie ich do celów stawianych dzieciom, ich oddziaływanie na poszczególne zmysły;

- formułowanie pytań i poleceń - ważne, aby nauczyciel mówił wolno i dobitnie, a polecenia były zrozumiałe dla dzieci; powinny być problemowe i otwarte, ponieważ takie inspirują do wypowiedzi wielozdaniowych;

- język nauczyciela - bogate słownictwo, ale jednocześnie dostosowane do poziomu dzieci;

- zachowanie właściwych proporcji między aktywnością nauczyciela i wychowanka;

- zróżnicowanie pracy indywidualnej w zależności od umiejętności dzieci;

- sprawne, dostosowane do możliwości dzieci tempo pracy, aktywność dzieci;

- stosunek do dzieci, indywidualne podejście - pogodna atmosfera, wykorzystanie indywidualnych umiejętności i zdolności dzieci;

- modyfikacja zajęć - o ile sytuacja tego wymagała;

- styl własny i twórczość;

- ocena samooceny - teoretyczne uzasadnienie swojego postępowania, krytyczne i refleksyjne ustosunkowanie się do przeprowadzonych zajęć (Fronckiewicz, Kołodziejska 2008, s. 43 i nn.; Gruchlik, Łukaszewska 2005, s. 18 i nn.).

Dyrektor omawiając hospitowane zajęcia, powinien rozpocząć od aspektów pozytywnych, a następnie przejść do ewentualnych niedociągnięć i błędów oraz 
wydać zalecenia wraz z określeniem terminów ich realizacji. Instruktaż oraz rady i wskazówki udzielane przez dyrektora mają na celu:

- wykrycie zmian w pracy nauczyciela,

- budzenie wiary we własne siły,

- potęgowanie ambicji zawodowej,

- kreowanie na doskonałość.

Wartość hospitacji podnosi prowadzenie jej we właściwej atmosferze. Dlatego też w trakcie trwania hospitacji i rozmowy pohospitacyjnej ważne jest „dostrzeganie i akcentowanie pozytywnych momentów. Taka forma oceny powoduje, że wskazane usterki i niedociągnięcia są przyjmowane przez nauczyciela ze zrozumieniem" (Leśkiewicz 1988, s. 220). Postawa i działania dyrektora winny utwierdzić nauczyciela $\mathrm{w}$ tym, że nadrzędnym celem pracy dydaktyczno-wychowawczej jest dobro dziecka. Uważa się również, że „omówienie wyników hospitacji powinno wzbogacić wiedzę i umiejętności zawodowe nauczyciela oraz dostarczyć mu inspiracji do coraz lepszej, bardziej wydajnej i twórczej pracy" (Kobyliński 1997, s. 403). Hospitację można potraktować jako wzajemne uczenie się od siebie (Wolan 2004, s. 19-22). Pogląd taki prezentuje m.in. Krzysztof. Wiczkowski, który uważa, że „efekty będą żadne lub nikłe, jeśli nauczyciel nie będzie chętny do wzbogacenia swej wiedzy i umiejętności (Wiczkowski 1997, s. 32). Hospitacja powinna rozwijać „samoocenę, samokontrolę, samokształcenie i autokreację" (Wiczkowski 1997, s. 32).

Prowadzenie rozmów pohospitacyjnych z nauczycielami (zwłaszcza z krótkim stażem zawodowym) umożliwia im nabywanie doświadczenia zawodowego oraz pozwala kształtować pożądane nawyki. Ponadto refleksja nad własną pracą wyzwala aktywność nauczyciela. Należy tu jeszcze raz podkreślić, że prowadzenie nadzoru pedagogicznego przez dyrektora $\mathrm{w}$ atmosferze współpracy $\mathrm{z}$ hospitowanym pozwala na kształtowanie refleksyjno-diagnostycznej postawy nauczyciela, co z kolei wpływa na stałe podnoszenie jego kwalifikacji zawodowych.

Skomplikowany proces kształcenia i wychowania młodego człowieka wymaga od nauczyciela dużej wiedzy i umiejętności. Żeby sprostać oczekiwaniom społecznym, nauczyciel powinien korzystać zarówno ze zorganizowanych form doskonalenia zawodowego, jak i dbać o swój rozwój poprzez ustawiczne samokształcenie.

Liczni teoretycy podają, że samokształcenia to świadome i dobrowolne starania o rozwój własnej osobowości, w tym wiedzy, poglądów, umiejętności, postaw i charakteru, w wyniku działań i celowego doboru wpływów otoczenia (Jaśko 2003, s. 412-416). Pod wpływem aktywności i oddziaływań zewnętrznych dochodzi do ciągu zmian osobowości nauczyciela uprawiającego samokształcenie. Samokształcenie jest szeroko ujętym procesem wkraczającym we wszystkie dziedziny działalności człowieka. Występuje w formie kształcenia na uczelniach i kursach, może być doskonaleniem zawodowym lub podnoszeniem kultury umysłowej, 
społeczno-moralnej, estetycznej i życia osobistego. Występuje również jako twórczość amatorska, konsumpcja dóbr materialnych, bądź refleksja osobista, pod warunkiem, że doprowadza do świadomego i dobrowolnego modyfikowania własnej osobowości. Samokształcenie jest więc procesem docierającym do wszystkich sfer osobowości pracującego nad sobą nauczyciela - intelektualnej, emocjonalnej i wolicjonalnej, przez co pobudza wyobraźnię i aktywność (Zalewska-Bujak 2010, s. 58-59). W zależności od stopnia samodzielności osoby pracującej nad sobą samokształcenie może być kierowane lub samodzielne. Czynnik przeobrażający osobowość człowieka stanowi o samokształceniu poprzez naukę, sztukę, działalność społeczną, pracę lub zabawę (Szempruch 2000, s. 23). Ze względu na rozległość treściowa wyróżnia się samokształcenie jednostronne, rozwinięte i wielostronne. Natomiast ze względu na dominację sposobów osiągania celów mówi się o samokształceniu opartym na przyswajaniu, odkrywaniu, przeżywaniu i działaniu (Banach 2003, s. 5).

Świadome, celowe i zorganizowane samokształcenie jest ukierunkowane na osiąganie zamierzonych efektów. Dlatego też konieczne jest określenie jego celów, ustalenie metod i form pracy oraz opracowanie programu realizacji i kontroli uzyskiwanych wyników. Proces samokształcenia kształtuje się w określonych warunkach. Podstawowe z nich to:

- znajomość samego siebie, swoich braków, potrzeb i możliwości;

- posiadanie niezbędnego minimum wiedzy o metodach i środkach pracy nad sobą;

- odpowiednia motywacja do uprawiania samokształcenia;

- opanowanie niezbędnych umiejętności realizacyjnych;

- dostęp do środków uprawiania samokształcenia (Buczkowska-Gola 2002, s. 59-60).

Nauczyciel powinien dążyć do stopniowego osiągania wymienionych wymogów, a ponadto, uprawiając samokształcenie, powinien kontrolować jego przebieg i efekty oraz w miarę potrzeby wprowadzać odpowiednie korekty (Filipowicz, Rataj 1988, s. 277).

W Polsce duże zdolności organizacyjne, w zakresie uruchamiania różnych form doskonalenia zawodowego nauczycieli, mają ośrodki metodyczne. Istotne znaczenie przypisuje się również zespołom samokształceniowym, gdzie chętni spotykają się w małych grupkach (Braże 2001, s. 98). Zadaniem Czesława Barańskiego zewnętrzne formy doskonalenia nauczycieli, inspirowane na zewnątrz, powinny być stopniowo ograniczane na rzecz doskonalenia wewnątrzszkolnego, ponieważ jest ono nie tylko tańsze, ale bardziej racjonalnie uzasadnione, gdyż każda placówka oświatowa charakteryzuje się innymi, specyficznymi problemami. Barański stwierdza, że „zadaniem placówek doskonalenia powinno być 
wyposażanie w umiejętności metodyczne, aby mogli oni [nauczyciele - przyp. A.N.-B.] sam w ramach rady pedagogicznej rozwiązać własne problemy" (Barański 1997, s. 30-32). Wewnątrzszkolne doskonalenie spełni swoje zadanie wtedy, gdy nauczyciele będą do tego zadania odpowiednio przygotowani i umotywowani wówczas to przedszkole będzie miało szansę doskonalić się i rozwijać samo bez impulsów zewnętrznych.

W placówkach wychowania przedszkolnego oprócz indywidualnego podnoszenia kwalifikacji zawodowych na studiach licencjackich, magisterskich i podyplomowych, najczęściej spotykane formy doskonalenia to:

- szkoleniowe rady pedagogiczne prowadzone w postaci hospitacji (Kania 1991), wymiany doświadczeń między nauczycielami bądź zapoznawanie się z nowościami literatury pedagogicznej;

- kursy przedmiotowo-metodyczne oferowane przez ośrodki metodyczne;

- spotkania i warsztaty metodyczne organizowane przez nauczycieli - doradców metodycznych (Elsner 2004, s. 16-17).

Ta ostatnia forma jest szczególnie cenna, ponieważ prowadzona jest przez profesjonalistów współpracujących z ośrodkami metodycznymi. Zadaniem doradców metodycznych jest udzielanie nauczycielom pomocy dydaktyczno-wychowawczej, rozwiązywanie problemów pedagogicznych oraz inicjowanie udziału nauczycieli $\mathrm{w}$ różnych formach doskonalenia zawodowego. Nauczyciele współpracując z doradcami, rozwiązują różne problemy merytoryczne i metodyczne nurtujące ich w dobie szybkich przemian społeczno-politycznych, mających wpływ zarówno na sytuację rodziny, jak i oświaty przedszkolnej. Doradcy inspirują również rady pedagogiczne do działalności innowacyjnej oraz zapoznają z nowymi metodami pracy z dziećmi, zachęcają także do stałego samokształcenia zawodowego, prowadzą konsultacje indywidualne i zespołowe, proponują udział w zespołach metodycznych, konkursach przedmiotowo-metodycznych oraz w wykładach zaproszonych gości. Nauczyciele podczas spotkań metodycznych mają okazje zademonstrować ciekawe zajęcia i własne pomysły, a także nauczyć się czegoś nowego od innych nauczycieli (Braże 2001, s. 99-100).

Podsumowując, działalność dydaktyczno-wychowawcza i opiekuńcza przedszkola zmierza do wypracowania najefektywniejszego modelu działania wszystkich jej ogniw. Doskonalenie pracy dyrektora i nauczycieli wychowania przedszkolnego jest w tym procesie sprawą zasadniczą. Można powiedzieć, że nauczyciel jest wiecznym uczniem, a stałe podnoszenie kwalifikacji zawodowych przez różnorodne formy doskonalenia jest warunkiem jego powodzenia w pracy i stałego podnoszenia efektywności edukacyjnej placówki wychowania przedszkolnego, w której pracuje. Konieczność doskonalenia zawodowego nauczycieli jest szczególnie istotna w okresie ustawicznych przeobrażeń w oświacie. 
Stopień przygotowania kadry pedagogicznej do pracy z dziećmi w dużej mierze zależy od posiadanego wykształcenia i chęci samodoskonalenia, na co z kolei duży wpływ ma dyrektor przedszkola. Rozwój indywidualny nauczycieli nie będzie miał bowiem większego wpływu na rozwój placówki, jeżeli nabyta wiedza nie zostanie wykorzystana w praktyce z powodu braku sprzyjających warunków.

Celem doskonalenia zawodowego nauczycieli przedszkola sterowanego przez dyrektora placówki jest zawsze usprawnianie pracy nauczycieli, a pośrednio doskonalenie pracy przedszkola, dlatego ważne jest, aby dyrektor stwarzał odpowiednie warunki sprzyjające realizacji tych celów. Są to bowiem cele wspólne i tylko wspólnie mogą być realizowane. Wskazane jest wypracowanie demokratycznego stylu pracy nadzoru pedagogicznego opartego na zwiększeniu zaangażowania nauczycieli poprzez dążenie do samokontroli swoich działań pedagogicznych. Umiejętne włączanie nauczycieli do stałego podnoszenia kwalifikacji zawodowych i wdrażanie do systematycznej samooceny to warunek nowoczesnego sprawowania nadzoru pedagogicznego. Ustawiczne samodoskonalenie swojej pracy to przede wszystkim obowiązek dyrektora, który własną postawą daje przykład innym. Doskonalenie zawodowe nauczycieli powinno mieć charakter działania zorganizowanego, dlatego też obowiązkiem dyrektora jest opracowanie harmonogramu szkoleń, a następnie doprowadzenie do realizacji planu i systematycznego kontrolowania wykonawstwa. Ważne również jest, aby twórcza atmosfera gościła w przedszkolu na co dzień, a nie od czasu do czasu.

\section{LITERATURA}

Banach C., 1997, Kształcenie, dokształcanie i doskonalenie nauczycieli. W: W. Pomykało (red.), Encyklopedia pedagogiczna. Warszawa, Fundacja Innowacja, 294-295.

Banach C., 2003, Nauczyciel wobec zadań reformy i własnego rozwoju zawodowego. „Nowa Szkoła”, nr 2, 4-9.

Barański C., 1997, O formach doskonalenia nauczycieli. „Nowa Szkoła”, nr 1, 29-31.

Barański C., 1997/1998, Syndrom kwalifikacji dyrektora - innowatora. „Kierowanie Szkołą", nr 1 - wkładka, 4-6.

Braże T.G., 2001, Metodycy - nauczyciele w systemie edukacji ustawicznej. „Edukacja Dorosłych", nr 2, 97-100.

Buczkowska-Gola M., 2002, Doskonalenie zawodowe nauczycieli. „Edukacja Ustawiczna Dorosłych", nr 3, 58-65.

Bury M., Matczak M., 2007, Rozwój zawodowy nauczyciela a rozwój szkoły i dziecka. „Przegląd Edukacyjny”, nr 4, 2-3.

Duraj-Nowakowa K., 1981, Hospitacja jako forma wdrażania studentów do zawodu nauczyciela. „Nauczyciel i Wychowanie”, nr 1, 103-105. 
Duraj-Nowakowa K., 2002, Nauczyciel: kultura, osoba, zawód. Kielce, Dom Wydawniczy Kosiński.

Dziuk H., 1994, Proces hospitacyjny - „ściagawka” dla dyrektora. „Dyrektor Szkoły”, nr 10, 2-3.

Elsner D., 1997, Stwórzmy wspaniałe przedszkole: materiały samokształceniowe dla dyrektorów. Część 2. Chorzów, Mentor.

Elsner D., 2004, Doskonalenie kwalifikacji zawodowych nauczycieli: tak! ale jakich? „Dyrektor Szkoły”, nr 1, 16-17.

Elsner D., 2004, Od kursów i WDN do uczącej się organizacji. „Nowa Szkoła”, nr 4, 35-37.

Elsner D., Knafel K., 2000, Jak organizować wewnątrzszkolne doskonalenie nauczycieli? Chorzów, Mentor.

Filipowicz F., Rataj M., 1988, Vademecum młodego nauczyciela. Warszawa, WSiP.

Fronckiewicz B., Kołodziejska J., 2008, Hospitacja od A do Z: praktyczne rozwiąania. Warszawa, Fraszka Edukacyjna.

Gawlikowski E., 1971, Pedagogiczny poradnik hospitacyjny. Katowice, ZOZNP.

Gruchlik J., Łukaszewska A., 2005, ABC hospitacji: poradnik dla dyrektorów i nauczycieli. Toruń, AKER.

Jaśko M., 2003, Doskonalenie nauczycieli i oświatowej kadry kierowniczej w okresie przemian edukacyjnych. W: J. Kuźma, J. Morbitzer (red.), Nauki pedagogiczne $w$ teorii i praktyce edukacyjnej. T.I. Kraków: Wydawnictwo Naukowe Akademii Pedagogicznej w Krakowie, 409-428.

Kania J., 1991, O doskonaleniu samokształcenia rad pedagogicznych. Rzeszów, WOM. Kobyliński W., 1997, Nadzór pedagogiczny. W: W. Pomykało (red.), Encyklopedia pedagogiczna. Warszawa, Fundacja Innowacja, 403-404.

Kowolik P., Pośpiech L., 2009, Hospitacja jako podstawowa forma nadzoru pedagogicznego i kontroli w szkole wyższej. „Nauczyciel i Szkoła”, nr 1-2, 135-141.

Leśkiewicz B., 1988, Rola dyrektora przedszkola w wyzwalaniu aktywności nauczycieli. „Wychowanie w Przedszkolu” nr 4, 218-223.

Łaciak M., 1986, Dyrektor przedszkola jako najniższe ogniwo nadzoru pedagogicznego. „Problemy Oświaty na Wsi”, nr 2, 93-99.

Magda-Adamowicz M., 2008, Edukacja permanentna nauczycieli. W: S.M. Kwiatkowski (red.), Edukacja ustawiczna. Wymiar teoretyczny i praktyczny. Warszawa - Radom, Instytut Badań Edukacyjnych, Instytut Technologii Eksploatacji - Państwowy Instytut Badawczy, 93-99.

Marcinkiewicz K., 1996, Nadzór szkolny (pedagogiczny i administracyjny). „Dyrektor Szkoły”, nr 3, 5-7.

Miszczyk J., 2001, Organizacja nadzoru pedagogicznego dyrektora szkoły. „Inspiracje”, nr 3,2 . 
Okoń W., 1992, Słownik pedagogiczny. Warszawa, Wydawnictwo Naukowe PWN.

Parzęcki R., 2002, Doskonalenie, doskonałość i samodoskonalenie w życiu nauczyciela. „Edukacja Ustawiczna Dorosłych”, nr 4, 32-36.

Pery A., Dobrzyńska J., 2000, Strategia kształcenia ustawicznego nauczycieli. „Dyrektor Szkoły", nr 2, 2-7.

Pilich M., 2002, Obowiązki dyrektorów szkół a doskonalenie nauczycieli. „Gazeta Szkolna", nr 27, 8.

Plewka C., 2009, Uwarunkowania zawodowego rozwoju nauczycieli. Warszawa, Instytut Badań Edukacyjnych.

Puchalski Z., 2004, Rozwój szkoły i rozwój zawodowy nauczycieli. „Edukacja i Dialog”, nr 2, 33-36.

Szempruch J., 2000, Aksjologia w kształceniu i działaniu nauczycieli zreformowanej szkoły. „Nowa Szkoła”, nr 4, 22-26.

Wiczkowski K., 1997, Hospitacje, czyli rzecz o zapraszaniu. Ostrołęka, Wydawnictwo Stefan Podedworny.

Wolan T., 2004, Uczenie się nauczycieli przez doświadczenie. „Nowe w Szkole”, nr 2, $19-22$.

Zalewska-Bujak M., 2010, .Udział nauczycieli w przemianach edukacyjnych przełomu XX i XXI stulecia w Polsce. Katowice, Wydawnictwo Uniwersytetu Śląskiego.

\title{
DETERMINANTS OF DIRECTED PROFESSIONAL DEVEPOPMENT OF TEACHERS IN KINDERGARTEN CONDITIONS
}

\begin{abstract}
The author of the article has taken up the issue of conditions for the professional development of kindergarten teachers, with particular emphasis on the role of the director in this area. The aim of the professional development controlled by the director of the kindergarten is primarily to improve the work of the teacher, and indirectly to improve the work of the kindergarten. Therefore, it is important for the Director to create appropriate conditions conducive to the achievement of these objectives. These are common goals and can only be achieved jointly. Skilful management of teacher training by the director of the educational institution is a prerequisite for modern pedagogical supervision.
\end{abstract}

Keywords: kindergarten teacher, further training, observation of activities, self-education 